\title{
Quality of pro-market national institutions and firms' decision to invest in R\&D: evidence from developing and transition economies
}

\author{
Fulvio Castellacci ${ }^{1} \cdot$ Prince C. Oguguo $^{2} \cdot$ Isabel Maria Bodas Freitas $^{2}$
}

Received: 1 July 2021 / Revised: 7 December 2021 / Accepted: 30 December 2021 /

Published online: 29 January 2022

(c) The Author(s) 2022

\begin{abstract}
Does institutional quality affect firms' decision to invest in R\&D? This paper investigates the idea that well-functioning pro-market institutions spur firms' R\&D propensity by reducing transaction costs and uncertainties related to research and innovation activities. Evidence from the World Bank Enterprise Surveys on a large sample of firms in 57 developing and transition economies between 2002 and 2017 corroborates this idea. Controlling for countries' level of economic development, industry fixed effects and a number of firm-level characteristics, the results show that firms' propensity to invest in R\&D is higher in countries in which national institutions ensure socio-political stability and enforcement of law and contracts.
\end{abstract}

Keywords R\&D · Innovation · Institutional quality · Economic development · WBES data

\section{Introduction}

The efforts of firms to upgrade technological capabilities and invest in innovation are crucial in processes of catching up and economic development (Lee et al., 2021; Malerba \& Nelson, 2011). When combined with changes in knowledge, technology and demand, these efforts may lead to structural changes, economic transformations, catching up and changes in industrial leadership (Lee \& Malerba, 2017).

$\mathrm{R} \& \mathrm{D}$ and innovation are however costly and demanding activities, subject to high uncertainties, and that often generate profitability and economic benefits several years after companies begin to invest in technological upgrading. The possibilities

Fulvio Castellacci

fulvio.castellacci@tik.uio.no

1 TIK Centre, University of Oslo, Oslo, Norway

2 Grenoble Ecole de Management, Grenoble, France 
for firms' to invest in $R \& D$ and innovation are constrained by resource availability and idiosyncratic firm-level characteristics, as well as institutional characteristics of each national economy. Specifically, national pro-market institutions are important to ensure socio-political stability that spurs investments and reduce uncertainties related to R\&D, well-functioning legal institutions and contract enforcing systems that reduce transaction costs in R\&D collaborations, and an efficient IPRs system that enable firms to reap the benefits of innovative activities (Castellacci, 2015; Kafouros \& Aliyev, 2016).

Although the general idea that the quality of national institutions affects R\&D activities is well-known and central in the literature on national systems of innovation, prior literature on this topic has until now investigated this relationship focusing on country- and industry-level factors only. Various country-level studies show that $\mathrm{R} \& \mathrm{D}$ investments in a given country is correlated with its institutional quality, tertiary education system, and patent rights protection (e.g. Castellacci \& Natera, 2012; Wang, 2010). Further, industry-level studies show that sector-specific R\&D investments are associated with the quality of legal systems of OECD countries, especially in industries in which contract enforcement are crucial (Seitz \& Watzinger, 2017).

Extant research on this topic, though, has not yet investigated the specific relationship between country-level institutional quality, on the one hand, and firm-level decision to invest in R\&D, on the other. Given the set of domestic institutions, firms in different countries may face different opportunities and constraints to their innovative activities, different possibilities to mobilize resources for R\&D, and different opportunities to reap the related benefits (Alam et al., 2019; Choi et al., 2014; Munari et al., 2010). From a comparative institutional perspective, it is therefore paramount to investigate how firms' R\&D activities are shaped by the quality of national pro-market institutions. This is important because, as observed by Chang et al. (2006), innovation studies have not yet achieved a clear understanding of how firm-level strategies and innovative activities interact with the macro environment in which business companies operate.

The present paper tackles this gap in extant research by empirically studying the relationship between the quality of pro-market institutions and firms' propensity to invest in R\&D in a large sample of transition and developing countries. Our empirical analysis relies on two secondary datasets: (1) the World Bank Enterprise Surveys (WBES), providing information on more than 10,000 firms in 57 transition and developing countries between 2002 and 2017; (2) the World Governance Indicators (WGI), measuring different aspects of the national institutional setting. The focus of this analysis on firms in transition and developing economies is important, because previous literature on this topic has mostly focused on advanced economies, whose national institutions are typically better able to ensure the socio-political and legal conditions that facilitate economic activity and market transactions (Bothello et al., 2019). Little is known, though, about firms' decisions to invest in R\&D in developing countries, as well as whether and how national institutional differences influence firms' decision to invest in R\&D.

The results of our econometric analysis show that in developing countries that have higher quality of domestic pro-market institutions firms have on average a 
substantially higher propensity to invest in $R \& D$. The paper contributes to the catching up literature by showing that the extent to which national institutions facilitate pro-market interactions influence the possibilities for learning and building competences in developing and transition economies. Thus, while industrial policy targeted to support the development of a specific industrial sector may create incentives and resources for catching-up (Bodas Freitas \& Iizuka, 2012), ensuring a well-functioning institutional context that reduces uncertainties and transaction costs related to $\mathrm{R} \& \mathrm{D}$ is a necessary condition for that to occur.

The paper is organized as follows. Section 2 briefly reviews the relevant literature on and the role of institutional quality for R\&D investments. Section 3 presents the data and empirical methods. Section 4 presents the results. Section 5 concludes the paper and discusses the implications of our findings.

\section{Theory}

R\&D is crucial for advancing capabilities for the development, acquisition and modification of technologies (Kim \& Kogut, 1996), and it increases firms' profitability, growth and economic performance (Capasso et al., 2015). Investment in R\&D is then key in processes of industrial catching up (Kim, 1997, 1998).

Institutional economics theory points out that firms' decisions are shaped by the national institutional context. This is because national institutions affect the transaction costs and learning opportunities related to different strategic alternatives (Jacobides \& Winter, 2012; North, 1990). Institutions may then benefit more business strategies than others (Castellacci, 2015; Chittoor et al., 2015), leading firms to develop different characteristics and capabilities in different institutional contexts (Freeman, 1995, 2004). The literature provides extensive evidence of how institutions influence firms' strategic decisions, especially their effects on market entry modes, and on the forms of governance of international alliances (Ang et al., 2015; Hagedoorn et al., 2005). Extant research, though, has not explicitly investigated how national institutions shape firms' decision to invest in R\&D.

Prior research studied the relationships between institutional quality and R\&D investments at the country-level and at the industry-level (Castellacci \& Natera, 2012; Seitz \& Watzinger, 2017; Wang, 2010). These studies show that R\&D investment is associated with the efficiency of the national legal systems in enforcing contracts, indicating for instance that in institutional contexts characterized by weak law enforcement, the expected positive effect of R\&D may be weaker (Qian et al., 2017). Indeed, evidence on OECD countries suggests that in industries in which contracts are more relevant for the functioning of the technological and production activities, the industry levels of R\&D investment are more responsive to the quality of national institutions (Seitz \& Watzinger, 2017). Alam et al. (2019) present a relevant empirical analysis of the relationships between national institutions and firms' R\&D intensity based on a panel of 664 firms from 20 transition and developing economies.

The present paper intends to contribute to this literature by investigating the relationship between the quality of pro-market institutions, on the one hand, and firmlevel decisions to invest in $\mathrm{R} \& \mathrm{D}$, on the other. Focusing explicitly on the firm-level 
of analysis, we posit four main channels through which institutional quality may affect agents' R\&D decision.

The first channel refers to uncertainties related to innovation. Since R\&D investments are subject to uncertainty and they typically lead to innovation output and profit several years after innovation investments are undertaken, national institutions may play an important role to reduce such uncertainties and thus strengthen firms' $R \& D$ incentives. In countries where the possibility to enforce contracts is low, the costs of engaging in opportunistic behavior and leakage crucial proprietary knowledge to competitors are low, thus raising the risks associated with investment in R\&D (Seitz \& Watzinger, 2017). In economies characterized by political and social instability, and where the legal systems do not efficiently enforce law and contracts, firms may perceive as likely to lose their investment as a result of crime and corruption or as a result of sudden changes in regulations that change unexpectedly the possibilities to bring new products to the market (Kafouros \& Aliyev, 2016).

A second channel linking national institutions to firms-level R\&D decision relates to companies' possibilities to reap the benefits of innovation. A well-functioning system of intellectual property rights (IPRs), combined with an efficient enforcement system, contributes to strengthen appropriability conditions related to innovation activities, and thus firms' incentives to carry out R\&D. Third, national institutions may also be important to facilitate firms' access to finance and venture capital that can spur R\&D activities. When policy programs to support firms' $R \& D$ are in place (e.g. subsidies, tax incentives), effectiveness and transparency of these programs foster firms' participation in public $R \& D$ funding, thus increasing $R \& D$ propensity in the national system.

Finally, a fourth channel relating the quality of pro-market institutions to firms' $R \& D$ decision refers to agents' interactions within the innovation system. Innovation typically involves interactions with a number of partners within and beyond the value-chain, between innovative companies, suppliers, users and public research institutions. Being innovation a social and interactive process (Lundvall, 2016), firms' efforts to innovate are likely to be influenced by the perceived costs of interacting and contracting with different partners, as well as by the possibilities to learn and appropriate value from the R\&D activities undertaken (Jacobides \& Winter, 2012). In countries in which national institutions have lower quality (e.g. in terms of legal institutions that regulate and enforce contracts in case of legal disputes among partners), firms perceive higher risk of interacting with external partners, as their innovation partners or technology suppliers may be also limited to comply timely and according to stipulated quality and standards.

Specifically, in a well-known study of courts and relational contracts in former Communist countries, Johnson et al. (2002) showed that well-functioning legal courts foster the development of new commercial relationships and contracts between producers and suppliers, since they help to settle legal disputes between partners when these arise. Further, when legal institutions are weak, there may arise informational asymmetries and hold up problems between suppliers and producers, so that the supplier will not invest an optimal amount of resources in relationspecific investments. This will affect firms' innovation incentives and performance, since hold up problems raise production costs and weaken comparative advantage. It 
has also been shown that such hold-up problems are more relevant in contract-intensive industries with more complex and differentiated products (Essaji \& Fujiwara, 2012; Ma et al., 2010; Nunn, 2007).

In summary, based on the four points noted above, our empirical analysis will investigate the hypothesis that firms' propensity to invest in $R \& D$ is on average higher in developing and transition economies that have higher quality of and better functioning national pro-market institutions.

\section{Data and methods}

\subsection{WBES survey methodology}

Information on firms is obtained from the Enterprise Surveys administered by the World Bank (WBES) in 57 transition and developing countries between 2002 and 2017 in Southeast and Central Europe; Eastern Europe, Caucasus and Central Asia; Latin America, Sub-Saharan Africa; South and Southeast Asia; Middle East and North Africa; and Western Asia. The WBES surveys focus on emerging economies (as defined by World Bank) and address establishments that are formally registered with the relevant authorities (excluding firms in the informal economy). The purpose of the surveys is to collect detailed information on the nature of the business activities, the ways in which firms operate, innovate and relate to their environment, as well as on their performance. Interviewees are typically top managers or business owners.

The surveys use a stratified random sampling. The strata for WBES are firm size, business sector, and geographic region within a country. Firm size levels are 1-5, 5-19, 20-99, and 100+employees (large-sized firms). Since in most economies a large majority of firms are small and medium-sized, WBES oversample large firms based on the understanding that larger firms tend to be important engines of job creation and economic growth. Sector breakdown by WBES is usually manufacturing, retail, and other services. For larger economies, specific manufacturing sub-sectors are selected as additional strata based on employment, value-added, and total number of establishments. In the WBES surveys, geographic regions within a country are selected based on which cities/regions collectively represent most of the economic activity. Each firm is thus associated with a single geographic region of residence, even though such firms may operate in markets outside of their home region.

The 15-year period of the study was between 2002 and 2017. This period was considered due to the similarities of the survey instruments used. Furthermore, we have restricted our sample in this study to manufacturing firms only, excluding firms in service and extractive industries. Given the cross-sectional nature of our study, we have excluded firms that were part of repeated longitudinal panel surveys (less than $10 \%$ of the population). After dropping missing values, unrealistic figures (such as negative values of firm size) and years with less than 100 observations, the sample consisted of 10,393 firms in 57 countries. 
Table 1 Sample firms by industrial sector

\begin{tabular}{|c|c|c|c|c|c|}
\hline Industry & $\begin{array}{l}\text { No R\&D } \\
\text { (fre- } \\
\text { quency) }\end{array}$ & $\begin{array}{l}\text { Performed } \\
\text { R\&D (fre- } \\
\text { quency) }\end{array}$ & $\begin{array}{l}\text { Performed } \\
\text { R\&D (per- } \\
\text { cent) }\end{array}$ & Total frequency & Total percent \\
\hline Electronics and machinery & 585 & 546 & 48.28 & 1131 & 10.88 \\
\hline Food, Beverage and tobacco & 1519 & 1257 & 45.28 & 2776 & 26.71 \\
\hline Metal products & 821 & 477 & 36.75 & 1298 & 12.49 \\
\hline $\begin{array}{l}\text { Petroleum, chemical, and } \\
\text { non-metallic mineral } \\
\text { products }\end{array}$ & 942 & 967 & 50.65 & 1909 & 18.37 \\
\hline Textile, garment and leather & 1782 & 756 & 29.79 & 2538 & 24.42 \\
\hline $\begin{array}{l}\text { Wood, paper, publishing } \\
\text { and furniture }\end{array}$ & 532 & 209 & 28.21 & 741 & 7.13 \\
\hline Total & 6181 & 4212 & 40.53 & 10,393 & 100 \\
\hline
\end{tabular}

Tables 1, 2 and 3 provide further information on the sample composition. Table 1 reports the industrial sectors represented in our sample, the number of firms in each manufacturing sector, and the number of firms that are engaged and not engaged in R\&D. Table 2 provides a list of the countries represented in these surveys, reporting again the number of respondent firms in each country and the corresponding number of $R \& D$ and non-R\&D companies. Table 3 reports the distribution of firms (total, R\&D active and non-R\&D active) by survey year during the period 2002-2017. In addition to WBES firm-level data, our study also uses the World Governance Indicators (WGI) to measure different aspects of the national institutional setting (see further below).

\subsection{Econometric model}

We seek to estimate firms' probability to invest in R\&D, as indicated in Eq. (1) below:

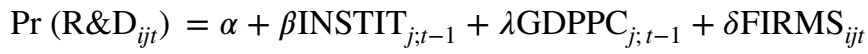

$$
\begin{aligned}
& +\rho \mathrm{INDUSTRY}+\gamma \mathrm{COUNTRY}+\omega \mathrm{YEAR}+\varepsilon_{i j t}
\end{aligned}
$$

where the sub-index $i$ indicates the firm, $j$ the country, and $t$ the year of the survey. The dependent variable $R \& D$ is a dichotomous variable that takes the value 1 if the firm indicated in the survey that it invested in R\&D during the preceding 3 years, and 0 otherwise. The main explanatory variable INSTIT accounts for the (lagged) quality of pro-market institutions 2 years before the corresponding survey year. Institutional quality is measured by using different variables available in the World Governance Indicators (WGI) database:

- Control of corruption captures perceptions of the extent to which public power is not exercised for private gain, including both petty and grand forms of corruption, as well as "capture" of the state by elites and private interests. 
Table 2 Sample firms by country

\begin{tabular}{|c|c|c|c|c|c|}
\hline Country & $\begin{array}{l}\text { No R\&D } \\
\text { (fre- } \\
\text { quency) }\end{array}$ & $\begin{array}{l}\text { Performed } \\
\text { R\&D (fre- } \\
\text { quency) }\end{array}$ & $\begin{array}{l}\text { Performed } \\
\text { R\&D (per- } \\
\text { cent) }\end{array}$ & Total frequency & Percent \\
\hline Southeast and Central Europe & 1389 & 1029 & 42.56 & 2418 & 23.27 \\
\hline Albania & 14 & 19 & 24.68 & 77 & 0.74 \\
\hline Bosnia and Herzegovina & 55 & 79 & 58.96 & 134 & 1.29 \\
\hline Bulgaria & 47 & 41 & 46.59 & 88 & 0.85 \\
\hline Croatia & 37 & 71 & 65.74 & 108 & 1.04 \\
\hline Czech Republic & 58 & 93 & 61.59 & 151 & 1.45 \\
\hline Estonia & 59 & 61 & 50.83 & 120 & 1.15 \\
\hline Hungary & 198 & 83 & 29.54 & 281 & 2.7 \\
\hline Kosovo & 41 & 15 & 26.79 & 56 & 0.54 \\
\hline Latvia & 65 & 26 & 28.57 & 91 & 0.88 \\
\hline Lithuania & 61 & 70 & 53.44 & 131 & 1.26 \\
\hline Montenegro & 13 & 3 & 18.75 & 16 & 0.15 \\
\hline North Macedonia & 72 & 41 & 36.28 & 113 & 1.09 \\
\hline Poland & 286 & 153 & 34.85 & 439 & 4.22 \\
\hline Romania & 218 & 96 & 30.57 & 314 & 3.02 \\
\hline Serbia & 20 & 42 & 67.74 & 62 & 0.6 \\
\hline Slovakia & 52 & 47 & 47.47 & 99 & 0.95 \\
\hline Slovenia & 49 & 89 & 64.49 & 138 & 1.33 \\
\hline $\begin{array}{l}\text { Eastern Europe, Caucasus and } \\
\text { Central Asia }\end{array}$ & 1468 & 878 & 37.43 & 2346 & 22.57 \\
\hline Armenia & 140 & 38 & 21.35 & 178 & 1.71 \\
\hline Azerbaijan & 51 & 4 & 7.27 & 55 & 0.53 \\
\hline Belarus & 45 & 43 & 48.86 & 88 & 0.85 \\
\hline Georgia & 79 & 38 & 32.48 & 117 & 1.13 \\
\hline Kazakhstan & 257 & 62 & 19.44 & 319 & 3.07 \\
\hline Kyrgyz Republic & 62 & 33 & 34.74 & 95 & 0.91 \\
\hline Moldova & 69 & 61 & 46.92 & 130 & 1.25 \\
\hline Russia & 383 & 377 & 49.61 & 760 & 7.31 \\
\hline Tajikistan & 97 & 44 & 31.21 & 141 & 1.36 \\
\hline Ukraine & 236 & 145 & 38.06 & 381 & 3.67 \\
\hline Uzbekistan & 49 & 33 & 40.24 & 82 & 0.79 \\
\hline Latin America & 2005 & 1666 & 45.38 & 3671 & 35.32 \\
\hline Argentina & 323 & 348 & 51.86 & 671 & 6.46 \\
\hline Bolivia & 50 & 48 & 48.98 & 98 & 0.94 \\
\hline Chile & 116 & 110 & 48.67 & 226 & 2.17 \\
\hline Colombia & 409 & 466 & 53.26 & 875 & 8.42 \\
\hline Dominican Republic & 31 & 15 & 32.61 & 46 & 0.44 \\
\hline El Salvador & 200 & 41 & 17.01 & 241 & 2.32 \\
\hline Guatemala & 103 & 67 & 39.41 & 170 & 1.64 \\
\hline Mexico & 47 & 54 & 53.47 & 101 & 0.97 \\
\hline Nicaragua & 54 & 22 & 28.95 & 76 & 0.73 \\
\hline
\end{tabular}


Table 2 (continued)

\begin{tabular}{|c|c|c|c|c|c|}
\hline Country & $\begin{array}{l}\text { No R\&D } \\
\text { (fre- } \\
\text { quency) }\end{array}$ & $\begin{array}{l}\text { Performed } \\
\text { R\&D (fre- } \\
\text { quency) }\end{array}$ & $\begin{array}{l}\text { Performed } \\
\text { R\&D (per- } \\
\text { cent) }\end{array}$ & Total frequency & Percent \\
\hline Paraguay & 64 & 43 & 40.19 & 107 & 1.03 \\
\hline Peru & 362 & 304 & 45.65 & 666 & 6.41 \\
\hline Uruguay & 229 & 139 & 37.77 & 368 & 3.54 \\
\hline Venezuela & 17 & 9 & 34.62 & 26 & 0.25 \\
\hline Sub-Saharan Africa & 574 & 330 & 36.50 & 904 & 8.7 \\
\hline Benin & 25 & 3 & 10.71 & 28 & 0.27 \\
\hline Cameroon & 24 & 4 & 14.29 & 28 & 0.27 \\
\hline Kenya & 88 & 73 & 45.34 & 161 & 1.55 \\
\hline Niger & 17 & 2 & 10.53 & 19 & 0.18 \\
\hline Nigeria & 230 & 93 & 28.79 & 323 & 3.11 \\
\hline Tanzania & 24 & 36 & 60.00 & 60 & 0.58 \\
\hline Uganda & 33 & 12 & 26.67 & 45 & 0.43 \\
\hline Zambia & 25 & 16 & 39.02 & 41 & 0.39 \\
\hline Zimbabwe & 108 & 91 & 45.73 & 199 & 1.91 \\
\hline South and Southeast. Asia & 179 & 31 & 14.76 & 210 & 2.02 \\
\hline Afghanistan & 14 & 1 & 6.67 & 15 & 0.14 \\
\hline Bangladesh & 39 & 23 & 37.10 & 62 & 0.6 \\
\hline Myanmar & 126 & 7 & 5.26 & 133 & 1.28 \\
\hline $\begin{array}{l}\text { Middle East, North Africa and } \\
\text { West. Asia }\end{array}$ & 566 & 278 & 32.94 & 844 & 8.12 \\
\hline Jordan & 106 & 16 & 13.11 & 122 & 1.17 \\
\hline Lebanon & 53 & 9 & 14.52 & 62 & 0.6 \\
\hline Morocco & 60 & 14 & 18.92 & 74 & 0.71 \\
\hline Turkey & 347 & 239 & 40.78 & 586 & 5.64 \\
\hline Total & 6181 & 4212 & 40.53 & 10,393 & 100 \\
\hline
\end{tabular}

- Rule of law measures perceptions of the extent to which agents have confidence in and abide by the rules of society, and in particular the quality of contract enforcement, property rights, the police, and the courts, as well as the likelihood of crime and violence.

- Regulatory quality is an indicator of the perceptions of the ability of the government to formulate and implement sound policies and regulations that allow and promote private sector development.

- Government effectiveness captures perceptions of the quality of public services, the quality of the civil service and the degree of its independence from political pressures, the quality of policy formulation and implementation, and the credibility of the government's commitment to such policies.

- Political stability and absence of violence/terrorism measures perceptions of the likelihood of avoiding political instability and/or politically motivated violence, including terrorism. 
Table 3 Sample firms by year

\begin{tabular}{llllll}
\hline Survey year & $\begin{array}{l}\text { No R\&D } \\
\text { (frequency) }\end{array}$ & $\begin{array}{l}\text { Performed R\&D } \\
\text { (frequency) }\end{array}$ & $\begin{array}{l}\text { Performed R\&D } \\
\text { (percent) }\end{array}$ & Total frequency & Percent \\
\hline 2002 & 44 & 407 & 90.24 & 451 & 4.34 \\
2005 & 1002 & 288 & 22.33 & 1290 & 12.41 \\
2006 & 431 & 380 & 46.86 & 811 & 7.8 \\
2008 & 573 & 286 & 33.29 & 859 & 8.27 \\
2009 & 1545 & 962 & 38.37 & 2507 & 24.12 \\
2010 & 798 & 982 & 55.17 & 1780 & 17.13 \\
2011 & 83 & 97 & 53.89 & 180 & 1.73 \\
2013 & 430 & 379 & 46.85 & 809 & 7.78 \\
2014 & 304 & 98 & 24.38 & 402 & 3.87 \\
2016 & 401 & 67 & 14.32 & 468 & 4.5 \\
2017 & 570 & 266 & 31.82 & 836 & 8.04 \\
Total & 6181 & 4212 & 40.53 & 10,393 & 100 \\
\hline
\end{tabular}

- Voice and accountability accounts for perceptions of the extent to which a country's citizens are able to participate in selecting their government, as well as freedom of expression, freedom of association, and a free media.

These indicators are defined by WGI based on aggregations of large numbers of local expert surveys and indexes using a statistical procedure based on an unobserved components model. Each of the six indicators was then rescaled in the WGI database in units of a standard normal distribution, with mean zero, standard deviation of one, and spanning between approximately -2.5 to 2.5 , with higher values corresponding to better institutional quality for all variables. Since it is well-known from previous studies that several indicators of institutional quality are highly correlated with each other (representing closely related and complementary aspects of countries' institutional quality), we have used these six indicators in a principal component analysis in order to reduce the multidimensionality of our explanatory factor. The principal component analysis yielded one single factor with Eigenvalue greater than 1, which accounts for $98 \%$ of the variance across all six variables. Cronbach's alpha is $93.9 \%$, suggesting that the six variables have high internal consistency and are closely related. In our econometric analysis, we will therefore use this composite factor as an overall measure of countries' institutional quality in baseline regressions, and we will also use each of the six indicators in additional separate regressions to test the effect of the various institutional indicators.

Our regression model includes a number of control variables. Evidence suggests that countries where the level of economic development is higher tend to have institutions that facilitate market transactions (Seitz \& Watzinger, 2017). Thus, we control for the (lagged) level of economic development of the country 2 years before the corresponding survey years. GDP per capita indicates the ratio of the gross domestic product of a country in purchasing power parity terms, measured in international 
dollars, to the population of the country. This variable is obtained from the World Bank based on reporting from national governments.

Regarding firm level controls, we include a number of standard variables. Firms that trade (import or export) have been shown to be more likely to invest in R\&D (Alvarez \& Robertson, 2004; MacGarvie, 2006). We thus include two dichotomous variables. Importer indicates firms that import raw materials directly (i.e. not through third-party intermediaries). Exporter indicates that a firm exports its products directly. Larger firms have more resources, and thus they may be more likely to invest in technology (Lee \& Sung, 2005; Shefer \& Frenkel, 2005; Veugelers, 1997). We then include the ordinal variable Firm size. It takes four different values between 0 and 3 (value 0 if the number of workers employed by a firm in the last fiscal year was less than five; whereas value 3 indicates that the firm had more than 100 workers). This ordinal variable is included as a continuous indicator in the regressions. We also account for the age of the firm since older firms may be more embedded in national institutions. Business group affiliation may affect a firms access to technological and financial resources for R\&D (Castellacci, 2015; Chang et al., 2006), and it is therefore important to include such control variable in the regressions. In addition, foreign direct investment may be a means of technology transfer that affects R\&D investment decisions (Arora \& Fosfuri, 2000; Saggi, 2002). We thus include two dichotomous variables in our model. The variable domestic subsidiary indicates subsidiaries that are less than $50 \%$ foreign owned. Foreign subsidiary takes value 1 if the firm has $50 \%$ or more foreign-owned capital. To account for the availability of financial resources we also include a variable called financial constraint, which is an ordinal variable with values ranging from 0 to 4 , where 0 indicates that the firm does not consider access to finance as an obstacle to its operations and higher values indicate that firms perceive access to finance as an important obstacle. This ordinal variable is included as a continuous indicator in the regressions. Srholec (2011) has previously shown that access to finance can affect investment in innovation in developing countries. Finally, industry, country and year account for the related set of fixed effects. Since our dependent variable is a dichotomous variable, we estimate our regression model using a probit regression with country, year and industry fixed effects and robust standard errors $(\varepsilon)$. All variables and sources are reported in a table in the appendix of the paper.

Before presenting the results, it is worth noticing some of the possible limitations of the econometric approach that we have used in our analysis, which are mostly related to the nature of the data that we have used. First, since R\&D activities unfold over time and are characterized by sunk costs and path-dependency, it would in principle be better to analyze them by using a dynamic panel framework, although this is not possible in the context of the pooled cross-sectional survey data that we are using. Second, some of the firm-level control variables in our regressions may be endogenous, such as e.g. firm size, import, export and financial constraints. Our main explanatory variable, though, is less subject to such possible issues as institutional quality is measured at the country level, and lagged 2 years vis-à-vis the dependent variable.

Finally, it is also possible that our results are subject to some sample bias related to the way in which the WBES survey was collected (e.g. large firms are 
over-represented as noted above). Nevertheless, our sample represents a large number of firms in all manufacturing sectors and a large number of transition and developing economies, such that the results are on the whole representative and robust.

\section{Results}

Table 4 reports descriptive statistics and the correlation coefficients among the variables. The correlation coefficients between the various firm level variables, and those among firm level variables and national variables are on the whole quite low, not suggesting possible issues of multicollinearity. On the other hand, the correlation coefficients among the various country-level governance indicators are as expected rather high, reason why we make use of the composite variable obtained through the principal component analysis in our baseline regressions.

Table 5 reports the results of the probit regression. Model 00 is the baseline model including only the control variables. Models 01-07 add the national institutional characteristics. The firm level controls behave as expected. The coefficients of importer, exporter, age, firm size, domestic subsidiary and financial constraints are positively correlated with firms' R\&D propensity. They indicate that R\&D propensity is on average higher for larger and older firms, for companies that import from and export to foreign markets, as well as for firms that are part of domestic business groups. The coefficient of the foreign subsidiary variable is non-significant. ${ }^{1}$

Shifting the focus to the main explanatory variable of our main interest, the estimated coefficient of the composite variable accounting for countries' quality of pro-market institutions is positive and significant, indicating a positive relationship between firms' propensity to invest in R\&D and the extent to which national institutions are able to provide socio-political stability and efficient legal institutions that reduce uncertainties and transaction costs related to $R \& D$ investments and innovative activities. The estimated coefficient of GDP per capita is also positive and significant. Our result on the role of institutional quality does therefore hold after controlling for countries' overall level of economic development. ${ }^{2}$

As the coefficients in our non-linear probit regression model do not provide an estimate of the marginal effects, we plot the related marginal effects. Figure 1 reports the marginal effect of the quality of pro-market institutions on the firms' probability

\footnotetext{
1 The variable measuring financial constraints is positively correlated with the dependent variable. In line with previous empirical analysis based on firm-level survey data (e.g. WBES surveys; CIS surveys), the interpretation of this positive correlation is that firms tend to be more aware of the importance of financial constraints when they engage in R\&D investments, since these require the availability of financial resources to be invested in uncertain and longer-term projects. In more general terms, survey-based obstacle indicators (such as the financial constraints variable used here) measure firms' perceptions and awareness of the importance of a given factor for the firm' strategy: the more important the factor, the more likely is that companies will perceive and report it as a critical aspect or obstacle to their operations and performance (Castellacci, 2015).

2 The Wald test comparing the two models $\left(X^{2}=15.61 ; p<0.001\right)$ indicates that the model including the pro-market institutions variable (model 01) is a significant improvement vis-à-vis the baseline model without this variable (model 00).
} 


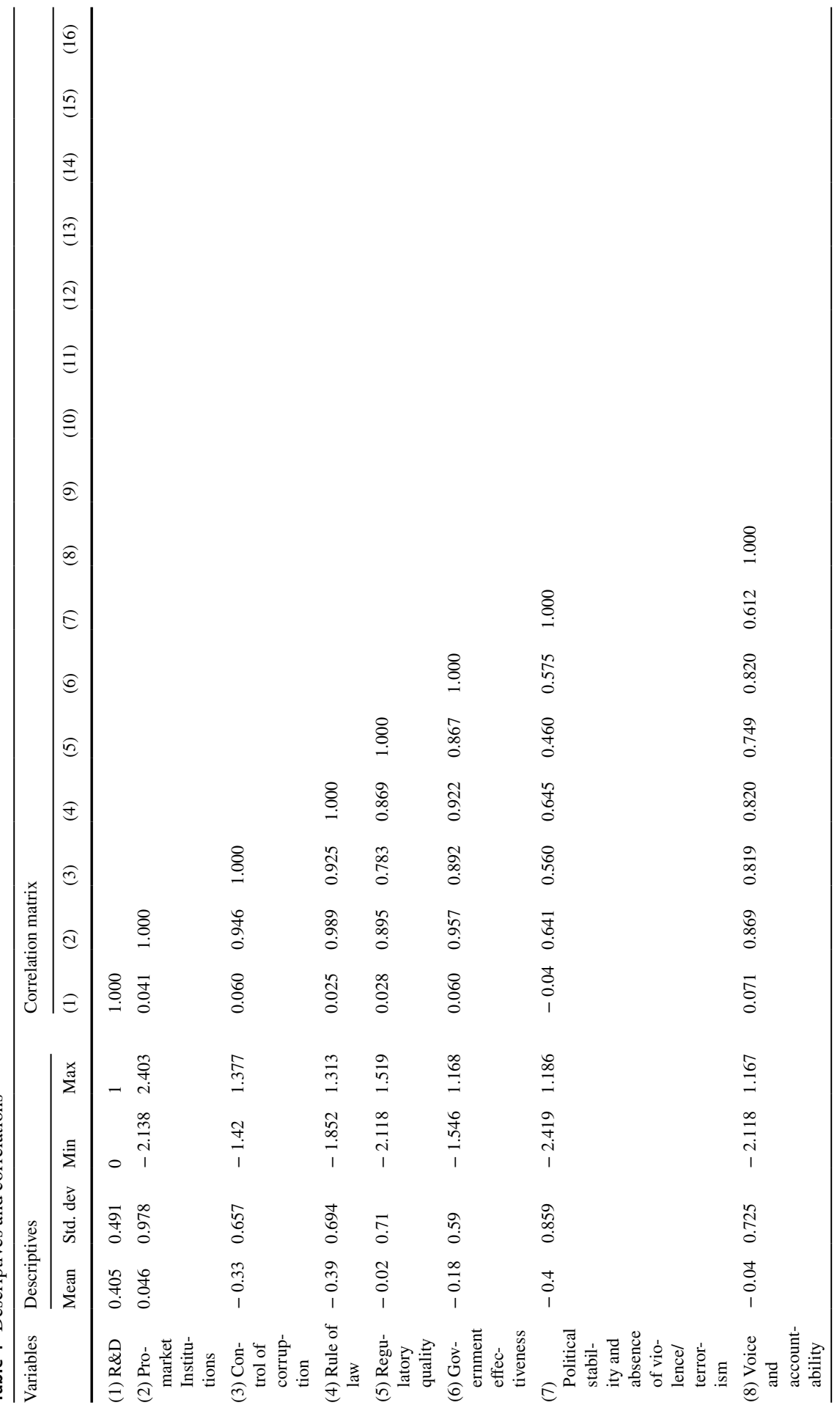




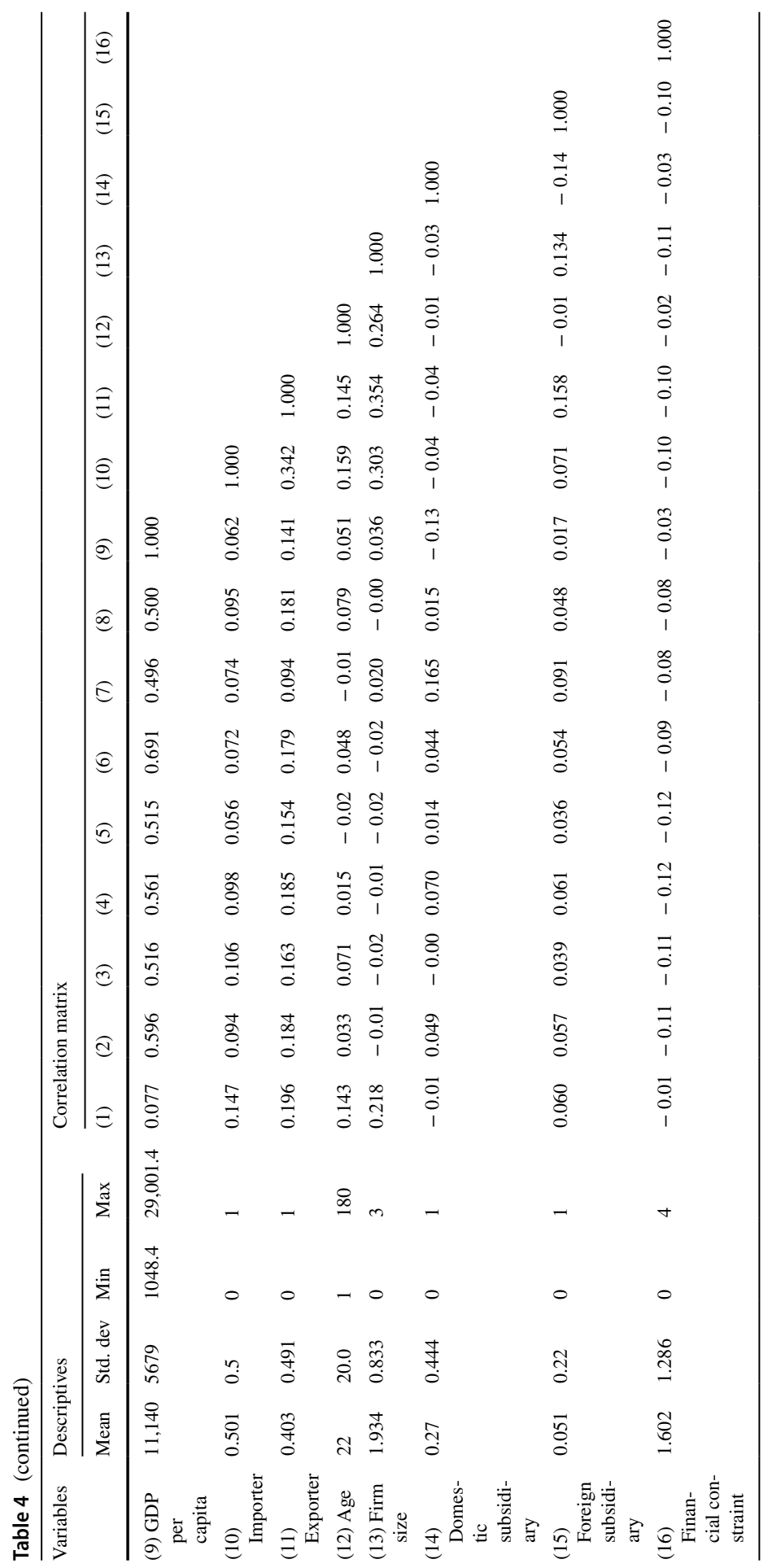


Table 5 Probit estimation of the probability to invest in R\&D

\begin{tabular}{lll}
\hline & $(00-$ controls only) & $(01$-full model $)$ \\
\hline GDP per capita & $0.0000441^{* *}(0.0000177)$ & $0.0000407 * *(0.0000178)$ \\
Importer & $0.200 * * *(0.0318)$ & $0.200^{* * *}(0.0319)$ \\
Exporter & $0.280 * * *(0.0329)$ & $0.275^{* * *}(0.0330)$ \\
Age & $0.00267 * *(0.000740)$ & $0.00260^{* * *}(0.000741)$ \\
Firm size & $0.250^{* * *}(0.0203)$ & $0.250^{* * *}(0.0203)$ \\
Domestic subsidiary & $0.114 * *(0.0442)$ & $0.108 * *(0.0443)$ \\
Foreign subsidiary & $0.0498(0.0725)$ & $0.0465(0.0727)$ \\
Financial constraint & $0.0187 *(0.0113)$ & $0.0180(0.0114)$ \\
Pro-market institutions & & $0.642 * * *(0.162)$ \\
Constant & $-5.585^{* * *}(0.754)$ & $-4.125 * * *(0.824)$ \\
Pseudo R & 0.1961 & 0.1965 \\
Log Pseudolikelihood & -5640.6629 & -5609.4582 \\
Wald $\mathrm{X}^{2}$ & $2666.46^{* * *}$ & $2667.24 * * *$ \\
Observations & 10,165 & 10,129 \\
\hline
\end{tabular}

Heteroskedasticity robust standard errors in parentheses. Country, industry, and survey year fixed effects are included but not shown

$* p<0.1, * * p<0.05, * * * p<0.01$

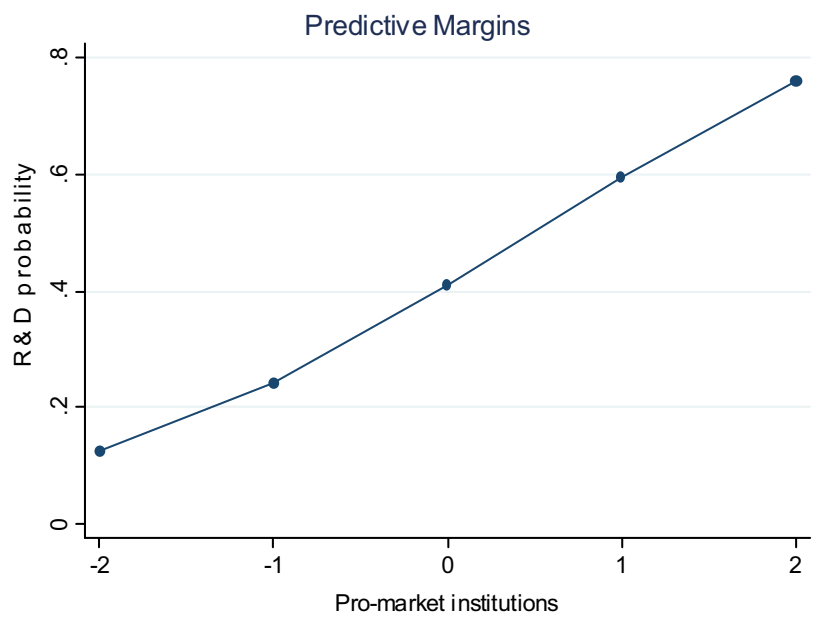

Fig. 1 Probability of a firm investing in R\&D based on national pro-market institutions

to invest in R\&D. The figure shows clearly that the probability to invest in R\&D increases steady and linearly with the quality of national pro-market institutions.

We undertook some robustness tests to further analyze our results. First, we examine the effect of each of the six WGI indicators in separate regressions to see if the results we obtained using the composite variable measuring the quality of promarket institutions are driven by any specific institutional characteristics. The results 
of these additional regressions (Table 6) show that the estimated coefficients of the variables measuring control of corruption, rule of law, government effectiveness and political stability and absence of violencelterrorism $(\mathrm{p}<0.01)$ and regulatory quality $(\mathrm{p}<0.05)$ are as expected positive and statistically significant. These relationships are illustrated further by means of the plots of the marginal effects for each of the five variables in Figs. 2, 3, 4, 5 and 6. The marginal effects show the same overall patterns noted for Fig. 1. On the other hand, the estimated coefficient of voice and accountability is lower than the others and less statistically precise (although the variable is closely correlated with the other institutional indicators, as reported in Table 4 above).

Second, we split our sample in two groups based on the countries' level of GDP per capita (above or below the median sample value of GDP per capita). Regression results reported in Table 7 show that in countries with GDP per capita below the sample median, the coefficient of quality of the pro-market institutions is positive and significant, whereas the same variable is not significant for the sub-sample of companies in countries with higher than average GDP per capita. This pattern suggests that less developed economies present on average a broader variation in institutional quality, such that $R \& D$ propensity of firms is higher for those countries that have better functioning institutional systems. On the other hand, economies that have higher GDP per capita levels have presumably lower cross-country variation in institutional quality, which may explain why the estimated coefficient is not significant in this sub-sample. In short, the result presented in this paper about the relationship between country-level institutional quality and firm-level R\&D propensity is mainly driven by the patterns of firms in less developed economies in our sample.

\section{Conclusions}

The catching up literature stresses the importance of firms' learning efforts and investments in technological upgrading, along with industrial policy (Lee et al., 2021; Malerba \& Nelson, 2011). Less attention has however been given to the characteristics of the national institutions in influencing firm's learning and innovating decisions. We address this gap by building on the institutional economics literature that argues that the extent to which national institutions facilitate market interaction defines firms' perceived transaction costs of alternative strategies. We propose that in countries where national institutions are less able to enforce law and contracts, and to assure political and social stability, firms will perceive higher transaction costs, and will therefore be less likely to invest in R\&D activities, which increasingly involve interaction and contracting with external partners.

Data on 57 developing and transition countries corroborate our expectations that the better the quality of the pro-market national institutions, the more likely that firms in that country will perceive low transaction costs in innovation activities, and thus the more likely that they will decide to invest in R\&D. This result is in line with the one obtained by the Seitz and Watzinger's (2017). In their industry-level analysis in OECD countries, they show that the observed industry levels of R\&D investment 


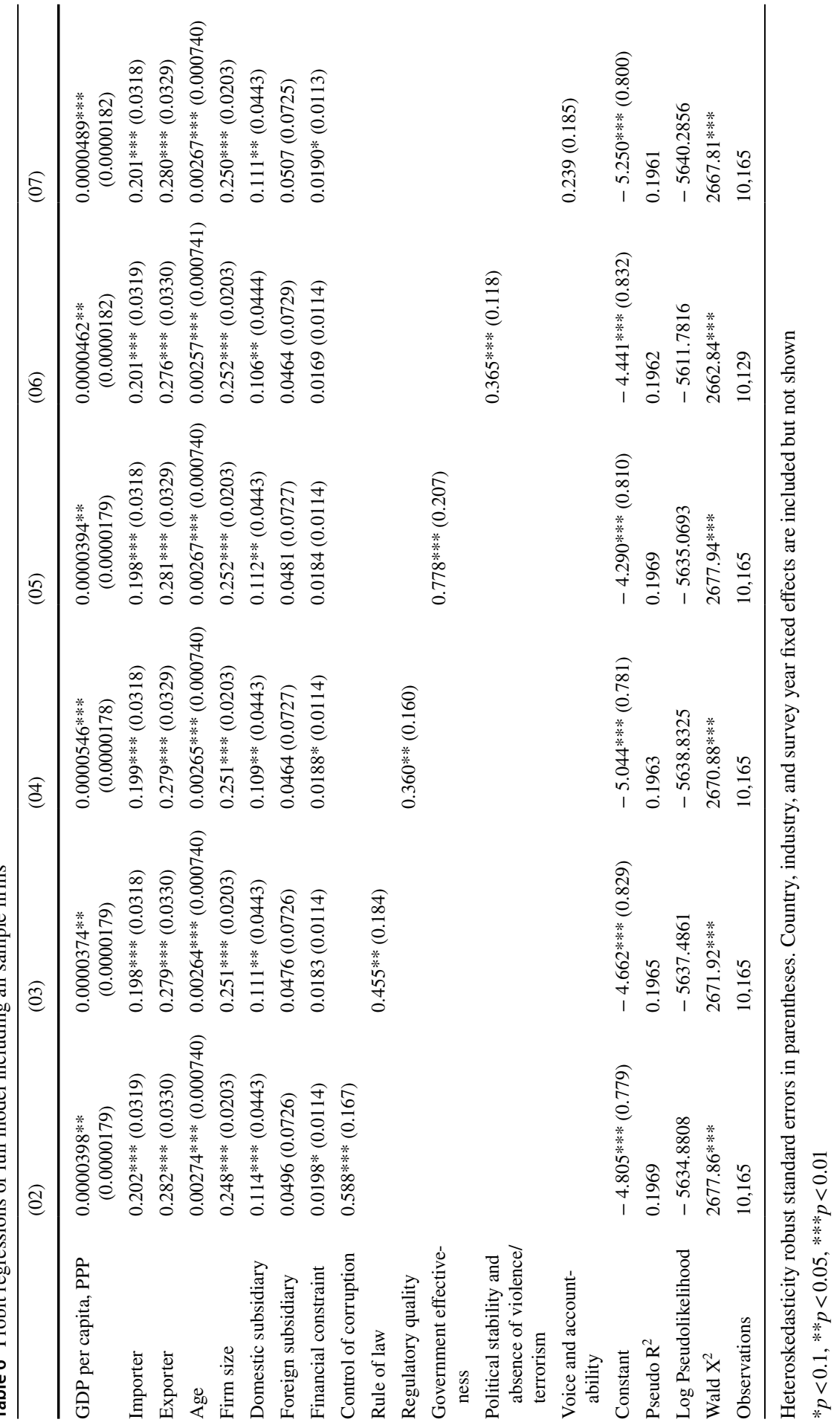




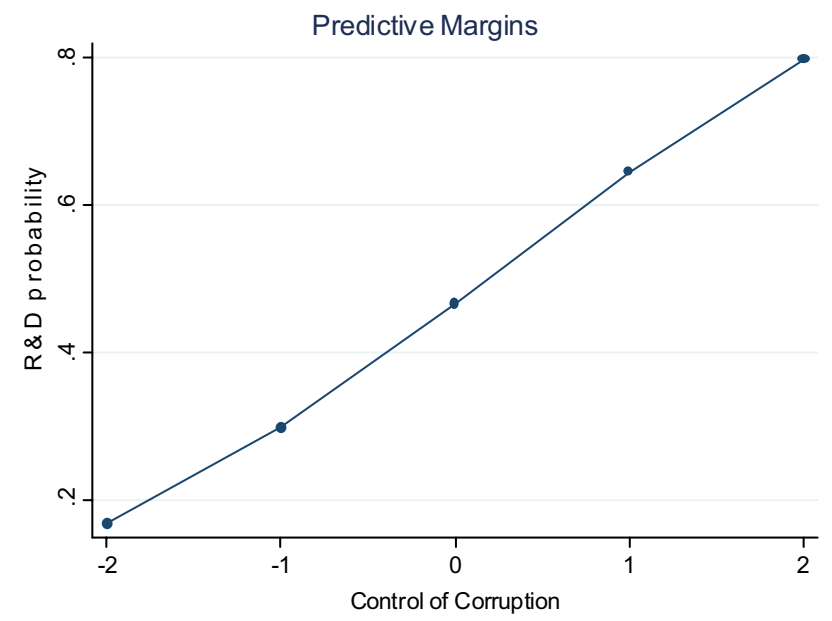

Fig. 2 Probability of a firm investing in $R \& D$ based on national control of corruption

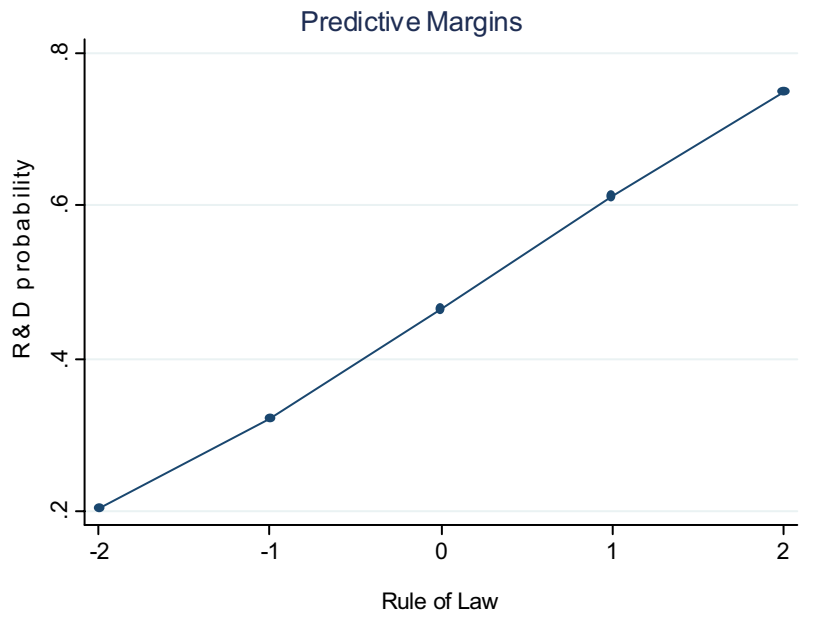

Fig. 3 Probability of a firm investing in R\&D based on national rule of law

in which contract enforcement is crucial are particular sensitive to the quality of national legal systems.

Our results hint at a necessary condition for catching up and economic growth, which is that national institutions can assure socio-political stability and enforcement of law and contracts. Only by perceiving a pro-market institutional environment firms may have more favorable perceptions of different catching-up strategies, and may perceive lower uncertainty and costs in investing in learning and innovation activities. When firms are reassured that the business markets will not suddenly change as result of socio-political instability, they will perceive investment in R\&D as less risky. The more firms are reassured about the possibility to enforce contracts, 


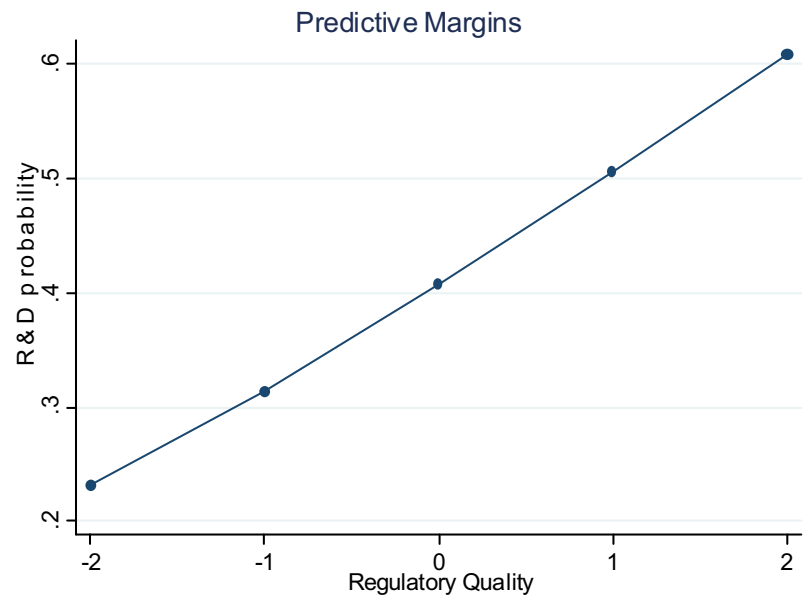

Fig. 4 Probability of a firm investing in R\&D based on national regulatory quality

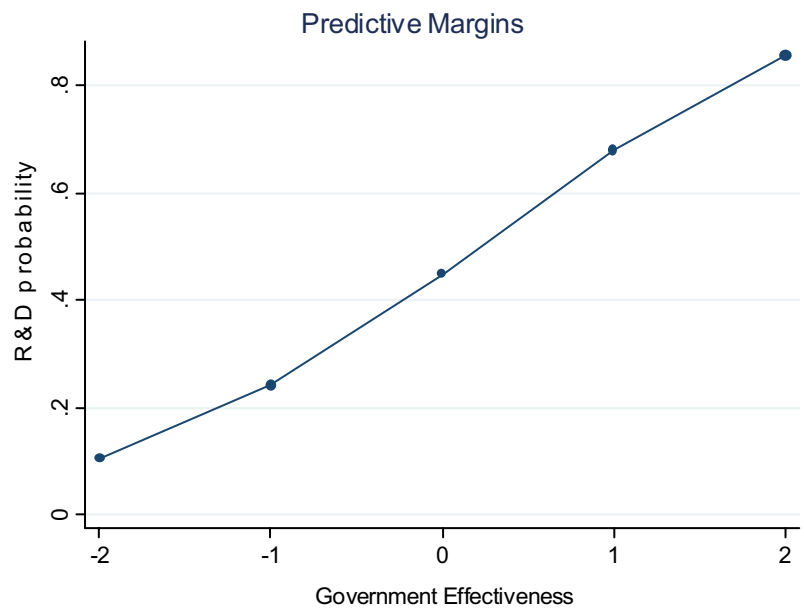

Fig. 5 Probability of a firm investing in R\&D based on national government effectiveness

the higher benefit they may perceive from contracting and collaborating with other firms for innovation, market entry and/or technology development. Results from the sample split exercise in particular corroborate this argument. The estimated coefficient of pro-market institutions is positive and significant (non-significant) for the sub-sample of firms in countries with GDP per capital lower (higher) than the sample median value.

This paper contributes to the catching up literature by proposing and showing that even small differences in the extent to which national institutions facilitate promarket interactions among developing and transition countries may significantly influence firms' engagement in learning and technological building activities. In 


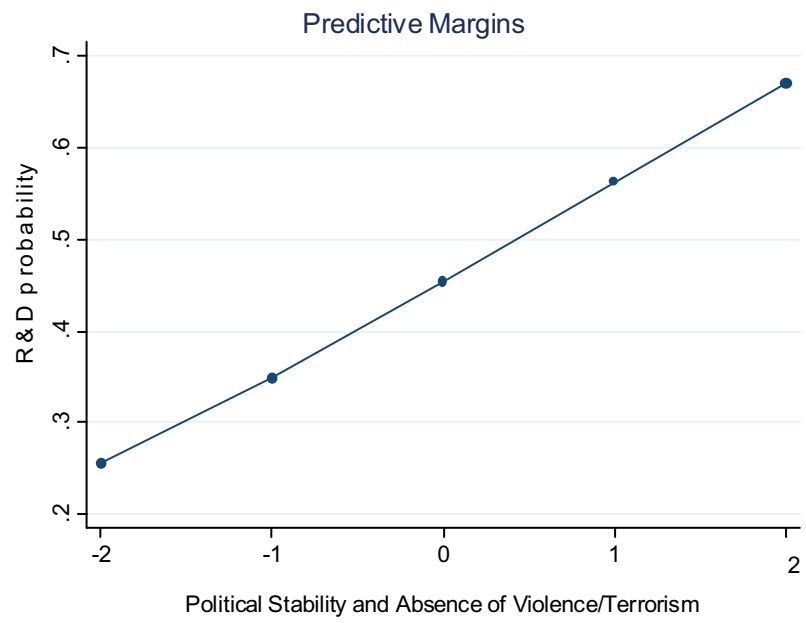

Fig. 6 Probability of a firm investing in R\&D based on national political stability and absence of violence/terrorism

Table 7 Probit regressions of full model, split sample for countries with GDP per capita levels above and below the median

\begin{tabular}{lll}
\hline & $\begin{array}{l}(01 \mathrm{~A}-\text { full model, below median GDP } \\
\text { per capita })\end{array}$ & $\begin{array}{l}\text { (01B-full model, above } \\
\text { median GDP per capita) }\end{array}$ \\
\hline GDP per capita & $-0.0000204(0.0000624)$ & $0.0000765(0.0000802)$ \\
Importer & $0.251^{* * *}(0.0454)$ & $0.156^{* * *}(0.0456)$ \\
Exporter & $0.228^{* * *}(0.0474)$ & $0.326^{* * *}(0.0468)$ \\
Age & $0.00228^{* *}(0.00113)$ & $0.00264 * * *(0.000986)$ \\
Firm size & $0.239^{* * *}(0.0285)$ & $0.267 * * * 0.0296)$ \\
Domestic subsidiary & $0.186^{* * *}(0.0663)$ & $0.0471(0.0614)$ \\
Foreign subsidiary & $0.344^{* * *}(0.107)$ & $-0.181^{*}(0.100)$ \\
Financial constraint & $0.00920(0.0162)$ & $0.0255(0.0163)$ \\
Pro-market institutions & $0.533^{* *}(0.238)$ & $-0.177(0.920)$ \\
Constant & $-4.398^{* * *}$ & -2.716 \\
& $(0.895)$ & $(1.837)$ \\
Pseudo R & 0.2189 & 0.1503 \\
Log pseudolikelihood & -2719.7658 & -2757.7945 \\
Wald $X^{2}$ & $1685.82^{* * *}$ & $7931.51 * * *$ \\
Observations & 5226 & 4775 \\
\hline
\end{tabular}

Heteroskedasticity robust standard errors in parentheses. Country, industry, and survey year fixed effects are included but not shown

$* p<0.1, * * p<0.05, * * * p<0.01$

addition, we contribute by showing that the direct influence of pro-market institutions on firms' investment decision in capability building and innovation is particular relevant in countries with low levels of development. This is in line with the 
literature studying the middle income country trap in processes of catching up and economic development (Lee et al., 2021).

\section{Appendix 1: Variables: definition and sources}

\begin{tabular}{|c|c|c|}
\hline Variable & Definition & Source \\
\hline $\mathrm{R} \& \mathrm{D}$ & $\begin{array}{l}\text { Dummy variable that takes the value } 1 \text { if the } \\
\text { firm has invested in R\&D during the preced- } \\
\text { ing } 3 \text { years, and } 0 \text { otherwise }\end{array}$ & Enterprise surveys \\
\hline Pro-market Institutions & $\begin{array}{l}\text { Principal component of control of corruption, } \\
\text { rule of law, regulatory quality, govern- } \\
\text { ment effectiveness, political stability and } \\
\text { absence of violence/terrorism, and voice and } \\
\text { accountability }\end{array}$ & Enterprise surveys \\
\hline
\end{tabular}

Control of corruption

The extent to which public power is not

World governance indicators exercised for private gain, including both petty and grand forms of corruption, as well as "capture" of the state by elites and private interests

Rule of law

The extent to which agents have confidence in and abide by the rules of society, and in particular the quality of contract enforcement, property rights, the police, and the courts, as well as the likelihood of crime and violence

Regulatory quality

The ability of the government to formulate and implement sound policies and regulations that permit and promote private sector development

Government effectiveness The quality of public services, the quality of the civil service and the degree of its independence from political pressures, the quality of policy formulation and implementation, and the credibility of the government's commitment to such policies

Political stability and absence of violence/ terrorism

Voice and accountability

GDP per capita

Importer

Exporter
The likelihood of avoiding political instability and/or politically motivated violence, including terrorism

The extent to which a country's citizens are able to participate in selecting their government, as well as freedom of expression, freedom of association, and a free media

The ratio of the gross domestic product of a country in purchasing power parity terms, measured in international dollars, to the population of the country

The firm imports raw materials directly (i.e. not through third-party intermediaries)

The firm exports its products directly
World governance indicators

World governance indicators

World governance indicators

World governance indicators

World governance indicators

National governments, compiled by World Bank

Enterprise surveys

Enterprise surveys 


\begin{tabular}{|c|c|c|}
\hline Variable & Definition & Source \\
\hline Age & $\begin{array}{l}\text { Number of years that the firm has been in } \\
\text { operation }\end{array}$ & Enterprise surveys \\
\hline Firm size & $\begin{array}{l}\text { Number of workers at the firm (0: less than } \\
5 \text { employees; } 1: 5-19 \text { employees; } 2: 20-99 \\
\text { employees; 3: } 100 \text { or more employees) }\end{array}$ & Enterprise surveys \\
\hline Domestic subsidiary & $\begin{array}{l}\text { Firm belongs to a majority domestic-owned } \\
\text { business group }\end{array}$ & Enterprise surveys \\
\hline Foreign subsidiary & $\begin{array}{l}\text { Firm belongs to a majority foreign-owned } \\
\text { business group }\end{array}$ & Enterprise surveys \\
\hline Financial constraint & $\begin{array}{l}0 \text { indicates that the firm does not consider } \\
\text { access to finance as an obstacle to its } \\
\text { operations, and values from } 1 \text { to } 4 \text { indicate } \\
\text { increasing prominence of access to finance } \\
\text { as an obstacle }\end{array}$ & Enterprise surveys \\
\hline
\end{tabular}

Funding Open access funding provided by University of Oslo (incl Oslo University Hospital).

Open Access This article is licensed under a Creative Commons Attribution 4.0 International License, which permits use, sharing, adaptation, distribution and reproduction in any medium or format, as long as you give appropriate credit to the original author(s) and the source, provide a link to the Creative Commons licence, and indicate if changes were made. The images or other third party material in this article are included in the article's Creative Commons licence, unless indicated otherwise in a credit line to the material. If material is not included in the article's Creative Commons licence and your intended use is not permitted by statutory regulation or exceeds the permitted use, you will need to obtain permission directly from the copyright holder. To view a copy of this licence, visit http://creativecommons.org/licen ses/by/4.0/.

\section{References}

Alam, A., Uddin, M., \& Yazdifar, H. (2019). Institutional determinants of R\&D investment: Evidence from emerging markets. Technological Forecasting \&amp; Social Change, 138, 34-44.

Alvarez, R., \& Robertson, R. (2004). Exposure to foreign markets and plant-level innovation: Evidence from Chile and Mexico. The Journal of International Trade \&amp; Economic Development, 13(1), 57-87.

Ang, S. H., Benischke, M. H., \& Doh, J. P. (2015). The interactions of institutions on foreign market entry mode. Strategic Management Journal, 36(10), 1536-1553.

Arora, A., \& Fosfuri, A. (2000). Wholly owned subsidiary versus technology licensing in the worldwide chemical industry. Journal of International Business Studies, 31(4), 555-572.

Bodas Freitas, I. M., \& Iizuka, M. (2012). Openness to international markets and the diffusion of standards compliance in Latin America. A multilevel analysis. Research Policy, 41(1), 201-215.

Bothello, J., Nason, R. S., \& Schnyder, G. (2019). Institutional voids and organization studies: Towards an epistemological rupture. Organization Studies, 40(10), 1499-1512.

Capasso, M., Treibich, T., \& Verspagen, B. (2015). The medium-term effect of R\&D on firm growth. Small Business Economics, 45(1), 39-62.

Castellacci, F. (2015). Institutional voids or organizational resilience? Business groups, innovation, and market development in Latin America. World Development, 70, 43-58.

Castellacci, F., \& Natera, J. (2012). The dynamics of national innovation systems: A panel cointegration analysis of the coevolution between innovative capability and absorptive capacity. Research Policy, 42(3), 579-594.

Chang, S. J., Chung, C. N., \& Mahmood, I. P. (2006). When and how does business group affiliation promote firm innovation? A tale of two emerging economies. Organization Science, 17(5), 637-656. 
Chittoor, R., Kale, P., \& Puranam, P. (2015). Business groups in developing capital markets: Towards a complementarity perspective. Strategic Management Journal, 36, 1277-1296.

Choi, Y. R., Yoshikawa, T., Zahra, S. A., \& Han, B. H. (2014). Market-oriented institutional change and R\&D investments: Do business groups enhance advantage? Journal of World Business, 49(4), $466-475$.

Essaji, A., \& Fujiwara, K. (2012). Contracting institutions and product quality. Journal of Comparative Economics, 40(2), 269-278.

Freeman, C. (1995). The 'National System of Innovation' in historical perspective. Cambridge Journal of Economics, 19(1), 5-24.

Freeman, C. (2004). Technological infrastructure and international competitiveness. Industrial and Corporate Change, 13(3), 541-569.

Hagedoorn, J., Cloodt, D., \& Van Kranenburg, H. (2005). Intellectual property rights and the governance of international R\&D partnerships. Journal of International Business Studies, 36(2), 175-186.

Jacobides, M. G., \& Winter, S. G. (2012). Capabilities: Structure, agency, and evolution. Organization Science, 23(5), 1365-1381.

Johnson, S., McMillan, J., \& Woodruff, C. (2002). Courts and relational contracts. Journal of Law, Economics, and Organization, 18(1), 221-277.

Kafouros, M., \& Aliyev, M. (2016). Institutions and foreign subsidiary growth in transition economies: The role of intangible assets and capabilities. Journal of Management Studies, 53(4), 580-607.

Kim, D. J., \& Kogut, B. (1996). Technological platforms and diversification. Organization Science, 7(3), 283-301.

Kim, L. (1997). The dynamics of Samsung's technological learning in semiconductors. California Management Review, 39(3), 86-100.

Kim, L. (1998). Crisis construction and organizational learning: Capability building in catching-up at Hyundai Motor. Organization Science, 9(4), 506-521.

Lee, C. Y., \& Sung, T. (2005). Schumpeter's legacy: A new perspective on the relationship between firm size and R\&D. Research Policy, 34(6), 914-931.

Lee, K., Lee, J., \& Lee, J. (2021). Variety of national innovation systems (NIS) and alternative pathways to growth beyond the middle-income stage: Balanced, imbalanced, catching-up, and trapped NIS. World Development, 144, 105472.

Lee, K., \& Malerba, F. (2017). Catch-up cycles and changes in industrial leadership: Windows of opportunity and responses of firms and countries in the evolution of sectoral systems. Research Policy, 46(2), 338-351.

Lundvall, B. (2016). The learning economy and the economics of hope. Anthem Press.

Ma, Y., Qu, B., \& Zhang, Y. (2010). Judicial quality, contract intensity and trade: Firm-level evidence from developing and transition countries. Journal of Comparative Economics, 38(2), 146-159.

MacGarvie, M. (2006). Do firms learn from international trade? Review of Economics and Statistics, $88(1), 46-60$.

Malerba, F., \& Nelson, R. (2011). Learning and catching up in different sectoral systems: Evidence from six industries. Industrial and Corporate Change, 20(6), 1645-1675.

Munari, F., Oriani, R., \& Sobrero, M. (2010). The effects of owner identity and external governance systems on R\&D investments: A study of Western European firms. Research Policy, 39(8), 1093-1104.

North, D. (1990). Institutions, institutional change, and economic performance. Cambridge University Press.

Nunn, N. (2007). Relationship-specificity, incomplete contracts, and the pattern of trade. The Quarterly Journal of Economics, 122(2), 569-600.

Qian, C., Wang, H., Geng, X., \& Yu, Y. (2017). Rent appropriation of knowledge-based assets and firm performance when institutions are weak: A study of Chinese publicly listed firms. Strategic Management Journal, 38(4), 892-911.

Saggi, K. (2002). Trade, foreign direct investment, and international technology transfer: A survey. The World Bank Research Observer, vol. 17. https://academic.oup.com/wbro/article-abstract/17/2/191/ 1690468 .

Seitz, M., \& Watzinger, M. (2017). Contract enforcement and R\&D investment. Research Policy, 46(1), 182-195.

Shefer, D., \& Frenkel, A. (2005). R\&D, firm size and innovation: An empirical analysis. Technovation, 25(1), 25-32.

Srholec, M. (2011). A multilevel analysis of innovation in developing countries. Industrial and Corporate Change, 20(6), 1539-1569. 
Veugelers, R. (1997). Internal R\&D expenditures and external technology sourcing. Research Policy, 26(3), 303-315.

Wang, E. C. (2010). Determinants of R\&D investment: The extreme-bounds-analysis approach applied to 26 OECD countries. Research Policy, 39(1), 103-116.

Publisher's Note Springer Nature remains neutral with regard to jurisdictional claims in published maps and institutional affiliations. 